\title{
Betonarme Binaların Doğrusal Elastik ve Doğrusal Elastik Olmayan Zaman Tanım Alanında Analizlerinden Elde Edilen Sismik Taleplerin Karşıllaştırılması
}

\author{
Emrah Meral $^{1 *}$ \\ 1* Osmaniye Korkut Ata Üniversitesi, Mühendislik Fakültesi, İnşaat Mühendisliği Bölümü, Osmaniye, Türkiye, (ORCID: 0000-0002-7635-0432), \\ emrahmeral@osmaniye.edu.tr
}

(Uluslararası Araştırma-Geliştirme ve Tasarım Konferansı - 15-18 Aralık 2021)

(DOI: 10.31590/ejosat.1045535)

ATIF/REFERENCE: Meral, E. (2021). Betonarme Binaların Doğrusal Elastik ve Doğrusal Elastik Olmayan Zaman Tanım Alanında Analizlerinden Elde Edilen Sismik Taleplerin Karşılaştırılması. Avrupa Bilim ve Teknoloji Dergisi, (32), 183-190.

\section{$\ddot{O} \mathbf{z}$}

Bu çalışmada düşük ve orta yükseklikteki mevcut betonarme binaların doğrusal elastik ve doğrusal elastik olmayan zaman tanım alanında analizlerinden elde edilen sismik talepleri karşılaştırılmışıtır. 3-, 6- ve 9- katlı binaların her iki asal doğrultusu dikkate alınarak 12 adet deprem kaydıyla toplam 144 adet analiz gerçekleştirilmiştir. Analiz sonuçlarına göre binaların taban kesme kuvveti, tepe noktası ötelenme ve maksimum göreli kat ötelenme oranı gibi parametreleri kıyaslanmıştır. 3-katlı binalara ait ortalama taban kesme kuvveti oranı 6- ve 9- katlı binalara göre sırasıyla doğrusal analizde 1.19 ve 1.24 , doğrusal olmayan analizde ise 1.61 ve 2.88 kat fazla elde edilmiştir. Tepe noktası ve göreli kat ötelenmelerinin ortalamalarına bakıldığında, 9-katlı binaların deplasman taleplerinin 3- ve 6katlılara oranla daha yüksek olduğu görülmüştür. Doğrusal analizde taban kesme kuvveti talepleri fazla doğrusal olmayan analizde ise tepe noktası ve göreli kat deplasman talepleri yüksek hesaplanmıştır.

\section{Comparison of Seismic Demands Obtained from Linear and Nonlinear Time History Analysis of Reinforced Concrete Buildings}

\begin{abstract}
Seismic demands obtained from linear and nonlinear time history analyzes of low and mid-rise existing reinforced concrete buildings were compared in this study. A total of 144 analyzes were performed with 12 earthquake records taking into consideration both principal directions of 3-, 6- and 9-storey buildings. The parameters such as base shear force, roof drift and maximum interstory drift ratio of buildings were compared per the analysis results. The average base shear force ratio for 3-storey buildings was 1.19 and 1.24 in linear analysis and 1.61 and 2.88 times in nonlinear analysis higher than those of the 6- and 9-storey buildings, respectively. The average roof and interstory drift ratios show that the demands of 9-storey buildings are higher than values of 3- and 6-storey buildings. In linear analysis, the base shear force demands are calculated high whereas the roof and interstory displacement demands are computed high in nonlinear analysis.
\end{abstract}

Keywords: Time history analysis, Dynamic analysis, Reinforced concrete buildings.

\footnotetext{
*Sorumlu Yazar: emrahmeral@,osmaniye.edu.tr
} 


\section{Giriş}

Ülkemizde meydana gelen depremler sonucunda oluşan can ve ekonomik kayıpların büyüklüğü ülkemizdeki binaların deprem performanslarının incelenmesini ihtiyaç haline getirmiştir. Ülkemiz yapı stoğunun oldukça önemli bir kısmı düşük ve orta yükseklikteki betonarme yapılardan oluşmaktadır. Bu sebeple bu binaların depreme karşı davranışlarının algılanması sismik araştırma çalışmalarında büyük bir öneme sahiptir. Sismik taleplerin hesabı kolay olmasından dolayı, çeşitli yönetmeliklerde tek serbestlik dereceli sistemler (TSD) üzerinden yapılmaktadır. Yapıların depreme karşı davranışını gerçeğe daha yakın yansıtan 3 Boyutlu (3-B) zaman tanım alanında analiz hem zaman alması hem de işlem hacminin çok fazla olmasından dolayı tercih sebebi olmamaktadır. Yapıların sismik davranışlarının tahmin edilmesi için araştırmacılar tarafindan mevcut binalar ve zaman tanım alanında analizlerle çeşitli çalışmalar gerçekleştirilmiştir (Çelik, 2011; Önür, 2011; Özmen, 2011; Beşikçi, 2013; Özer ve ark., 2017).

Bir binanın değerlendirilmesi için kullanılabilecek yöntemler, yapının eleman davranışları göz önüne alınarak doğrusal ve doğrusal olmayan olarak iki gruba ayrılmaktadır. Doğrusal analizlerde yapı elemanlarının üstüne gelen tüm yükleri taşıyabileceği varsayımıyla; elemanların dayanımları gözönüne alınmaz ve elemanlarda herhangi bir akma olayı oluşmaksızın analiz süresince elastik davranacakları kabul edilir. Doğrusal olmayan yöntemlerde ise her eleman için dayanım-deformasyon bağıntıları tanımlanarak elamanların kapasiteleri dikkate alınır ve analiz süresince oluşabilecek rijitlik değişiklikleri hesaba katılır (Bilgin, 2007).

Zaman tanım alanında analiz, deprem yüklerinin yapıya direkt olarak uygulanarak analizlerin yapılmasından dolayı, yapı davranışının en gerçekçi şekilde incelendiği analiz olarak tanımlanır. Bunun yanında, en önemli özelliği analizlerin zor olması nedeniyle bu alanda çalışmaların sınırlı kalmasıdır (Meral, 2010; İnel ve ark., 2011; İnel ve ark., 2013; Inel ve ark., 2014; Inel ve Meral, 2016). Bu durumda oluşturulan modellerin ve kullanılan deprem ivme kayıtlarının çeşitliliğinin artırılması sonuçların geçerliliğini artırmak açısından gereklidir.

Çalışmanın amacı düşük ve orta yükseklikteki betonarme bina türü yapıların sismik davranışlarının doğrusal elastik ve doğrusal elastik olmayan zaman tanım alanında analizlerle belirlenip karşılaştırılmasıdır. Bu amaç doğrultusunda düşük ve orta yükseklikteki mevcut betonarme binalar 3-, 6- ve 9- katlı binalarla yansıtılmıştır. Mevcut binaların tasarımlarında 2007 Türk Deprem Yönetmeliği (DBYBHY-2007, 2007) göz önüne alınarak bina modelleri hazırlanmıştır. Bu bina modelleri geçmiş depremlerde kayıt altına alınan yer hareketi kayıtları arasından seçilen 12 adet kayıt kullanılarak her iki asal eksen doğrultusunda analiz edilmiştir. Zaman tanım alanında analizlerle elde edilen sismik talepler kat sayısına göre karşılaştırılarak değerlendirilmişstir. Elde edilen sonuçlarla çalışmanın araştırmacılar için doğrusal elastik ve doğrusal elastik olmayan zaman tanım alanında analizin 3 Boyutlu (3-B) binalar üzerindeki sismik talep farklılıklarının anlaşılması adına yararlı olacağı düşünülmektedir.
Düşük ve orta yükseklikteki binaları temsilen 3-, 6- ve 9-katlı bina modelleri tasarlanmıştır. Binaların kalıp planları Şekil 1a, $1 \mathrm{~b}$ ve $1 c^{\prime}$ de verilmiştir. Binalar 1. derece deprem bölgesinde süneklik düzeyi yüksek ve Z3 zemin sınıfı üzerinde yer aldığı varsayılarak 2007 Türk Deprem Yönetmeliği hükümleri dikkate alınarak modellenmiş̧ir. Tasarımda $25 \mathrm{MPa}$ beton basınç dayanımı göz önüne alınmıştır. Boyuna ve enine donatıların karakteristik akma dayanımları $420 \mathrm{MPa}$ alınmıştır. Binaların tasarımında ve analizlerinde SAP2000 yapısal analiz programı kullanılmıștır (SAP2000 V-19, 2017). Taşıyıcı sistem davranışı X ve Y yönünde perdesiz sadece çerçeveli olarak dikkate alınmıştır. Binalar konut olarak tasarlanıp kat yüksekliği $2.80 \mathrm{~m}$ alınmıştır. Çalışma kapsamında duvarların ağırlıkları göz önüne alınmış olup yatay dayanıma katkısı modellere yansıtılmamıştır. Yapılardaki döşemeler tasarım esanasında tanımlanmamış, döşemelerin ağırlıkları ve üzerindeki yükler bu döşemelerin yanındaki kirişlere düzgün yayılı yük olarak aktarılmıştır. Rijit diyaframlar farklı kat seviyelerinde uygulanmıştır. Binanın bir deprem doğrultusunun diğer deprem doğrultusuna göre baskın olmaması için kolonların uzun boyutunun yerleşiminin her iki yönde orantılı dağıtılmasına çalışılmıştır. Kolon boyutları, 2007 Türk Deprem Yönetmeliği (DBYBHY-2007, 2007) minimum dikdörtgen kolon boyutu ve kat sayısıyla doğru orantılı olarak artan kolon alanı/kat alanı (\%) değeri göz önüne alınarak seçilmiştir (Özmen, 2011). Kiriş ve kolanların boyuna donatı oranları kesitlerin $\% 1$ ' dolayında alınmıştır. Enine donatı olarak kolon ve kirişlerde $100 \mathrm{~mm}$ aralıklarla $8 \mathrm{~mm}$ çapında $(\phi 8)$ sadece tek etriyeli (çift kollu) donatılar kullanılmıştır.

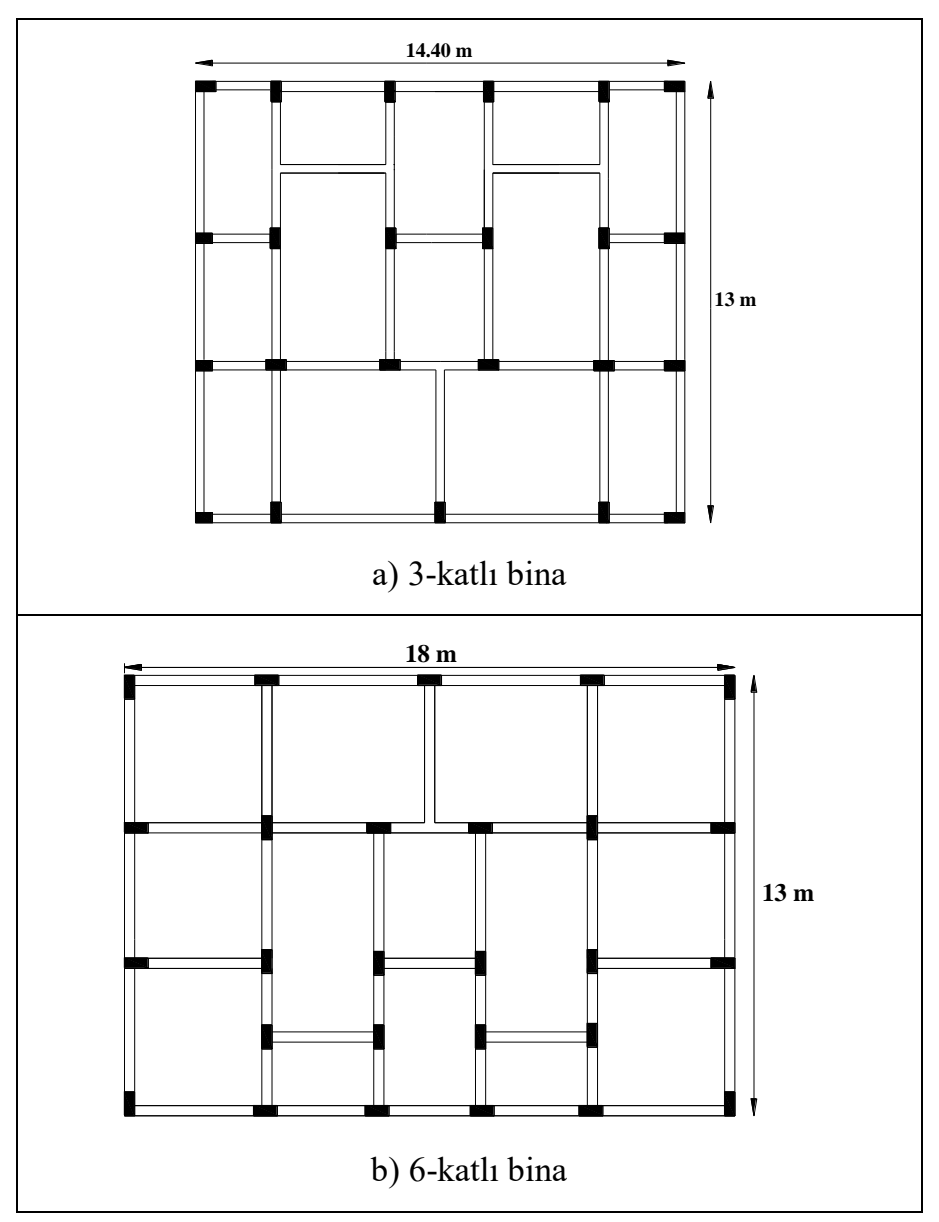

\section{Materyal ve Metot}

\subsection{Binaların Modellenmesi ve Yapısal Karakteristiklerinin Tanıtılması}




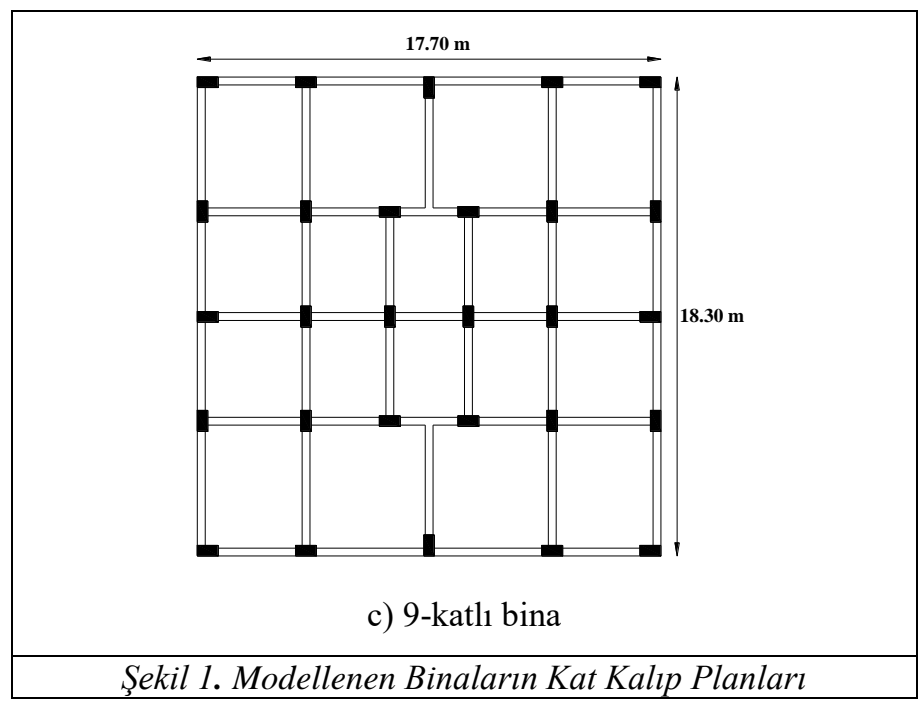

Doğrusal olmayan davranış yapı elemanların uçlarında tanımlanan plastik mafsallar sayesinde modellere yansıtılmıştır. Şekil 2 'de verildiği gibi, plastik mafsalın kuvvet-deformasyon davranışı için $\mathrm{A}, \mathrm{B}, \mathrm{C}, \mathrm{D}$ ve $\mathrm{E}$ noktaları tanımlanmıştır. $\mathrm{Bu}$ noktaların her biri için elemanın türü, malzeme dayanımları, boyuna ve enine donatı detayı ve eksenel yük durumu göz önüne alınmıştır. 3-, 6- ve 9- katlı bina türü yapıları için sırasıyla 915, 2094 ve 3384 plastik mafsal atanmıştır. Plastik mafsal uzunluğu DBYBHY-2007'nin önerdiği gibi kesit yüksekliğinin yarısı olarak alınmıştır. Çalışmada beton modeli için DBYBHY2007'de verilen Mander sargılı beton modeli kullanılmıştır (Mander ve ark.., 1988). Plastik mafsalların özelliklerinin belirlenmesi ve SAP2000'e aktarımı işlemi SEMAp yazılımından faydalanılarak gerçekleştirilmiştir (SEMAp, 2008). Doğrusal elastik ve doğrusal elastik olmayan zaman tanım analizlerinde Newmark ortalama ivme metodu dikkate alınmıştır.

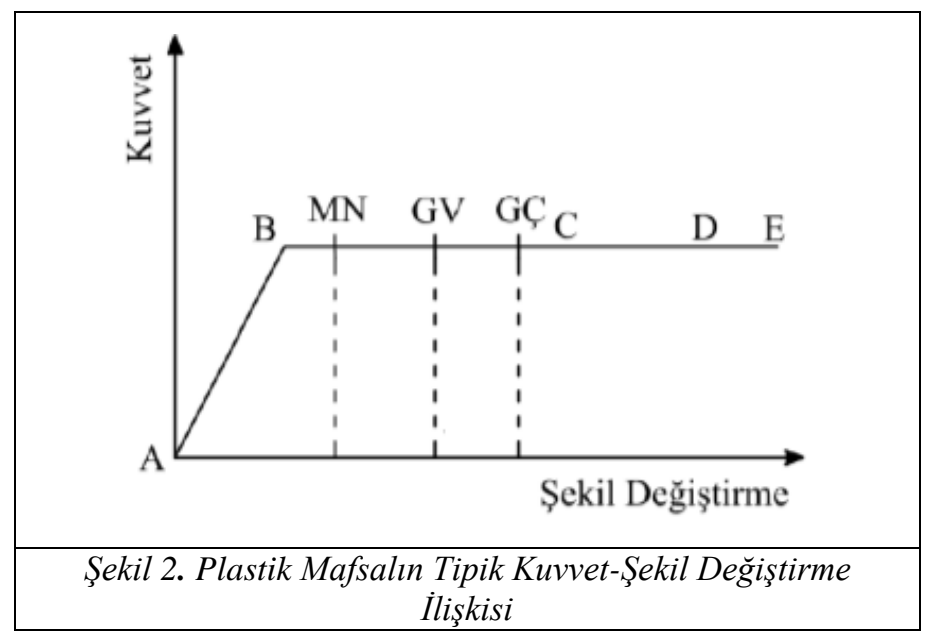

Çalışmada modellenen binaların yapısal özellikleri Tablo 1'de gösterilmektedir. Eğilme etkisine maruz betonarme elemanlarda çatlamış kesite ait etkin kesit rijitlikleri (EI)e kullanılmıştır (DBYBHY-2007, 2007). Her bir bina modeli için etkin eğilme rijitlik değerleri, kirişlerde 0.4EI ve kolonlarda ise eksenel yük oranına göre $0.4 \mathrm{EI}$ ve $0.8 \mathrm{EI}$ aralıklarında değerler gözönüne alınmıştır.

Tablo 1. Binalara Ait Karakteristik Özellikler

\begin{tabular}{|c|c|c|c|c|}
\hline Parametre & Yön & 3-katlı yapı & 6-katlı yapı & 9-katlı yapı \\
\hline \multirow[t]{2}{*}{ Binanın Boyutları (m) } & $\mathbf{X}$ & 14.4 & 18 & 17.7 \\
\hline & $\mathbf{Y}$ & 13 & 13 & 18.3 \\
\hline Bina Yüksekliği (m) & & 8.4 & 16.8 & 25.2 \\
\hline Bir Kattaki Kirişlerin Sayısı & & 36 & 40 & 45 \\
\hline Kiriş Boyutları (mm) & & $250 \times 500$ & $300 \times 600$ & $300 \times 700$ \\
\hline Bir Kattaki Kolonların Sayısı & & 23 & 27 & 28 \\
\hline Kolonların Boyutları (mm) & & $300 \times 600$ & $300 \times 700$ & $400 \times 800$ \\
\hline Kolon Alanı/Kat Alanı (\%) & & 2.21 & 2.42 & 2.77 \\
\hline \multirow[t]{2}{*}{ Tireşim Periyodu (s) } & $\mathbf{X}$ & 0.30 & 0.57 & 0.69 \\
\hline & $\mathbf{Y}$ & 0.32 & 0.52 & 0.76 \\
\hline Bina Ağırlığı (kN) & & 5922 & 16533 & 35231 \\
\hline
\end{tabular}

\subsection{Analizlerde Kullanılan Yer Hareketi Kayıtlarının Özellikleri}

Yer hareketi kayıtlarının seçiminde 2007 Türk Deprem Yönetmeliği'nde (DBYBHY-2007, 2007) Z3 sinifi zemin üzerinde 50 yılda aşılma olasılı $\breve{g}_{1} \% 10$ olarak tanımlanan standart tasarım tepki spektrumu ölçeklendirme için kullanılmıştır. Deprem çeşitliliği olacak şekilde toplamda 12 adet yer hareketi kaydının faya normal (FN) ve faya paralel (FP) olmak suretiyle iki yatay bileşeni kullanılarak ölçeklendirilmiş kayıtların özellikleri Tablo 2'de açıklanmıştır. Yer hareketi kayıtları PEER web sitesinden alınmıştır (Peer, 2011).

Seçilen 12 depremin spektrumlarının ortalaması alındığında DBYBHY-2007'nin 50 yılda aşılma olasılı̆̆ $\% 10$ olan depremin Z3 zemin grubu üzerindeki spektruma oldukça yaklaştığı Şekil 3 'te görülmektedir.

e-ISSN: 2148-2683

\section{Bulgular ve Tartışma}

\subsection{Sismik Taleplerin Değerlendirilmesi}

Toplam 144 adet 3-B doğrusal elastik ve doğrusal elastik olmayan analizlerden elde edilen taban kesme kuvveti, tepe noktası ve maksimum göreli kat ötelenme oranları gibi değişkenler karşılaştırılmıştır. Analizlerden bulunan verilere göre, modellerin taban kesme kuvveti, modellerin yatay dayanımı kadardır.

Karşılaştırmaların anlaşılabilir olması için çalışma kapsamında yapılan analizlerden bulunan taban kesme kuvvetleri yapının ağırlığına bölünerek "taban kesme kuvveti oranı”, tepe noktası deplasmanları yapı düşey uzunluğuna bölünerek "tepe noktası ötelenme oranı” ve göreli kat deplasmanları da kat 
Tablo 2. Çalışmada Analizlerde Kullanılan Yer Hareketi Kayıtlarının Özellikleri

\begin{tabular}{|c|c|c|c|c|c|c|c|c|}
\hline No & Deprem Adı & Yil & İstasyon & Bileşen & $\begin{array}{c}\text { Ölçek } \\
\text { Faktörü }\end{array}$ & $\begin{array}{c}\text { PGA } \\
\text { (g) }\end{array}$ & $\begin{array}{l}\text { PGV } \\
(\mathbf{c m} / \mathbf{s})\end{array}$ & $\begin{array}{l}\text { Vs30 } \\
(\mathrm{m} / \mathbf{s})\end{array}$ \\
\hline 1 & \multirow{2}{*}{ Big Bear } & \multirow{2}{*}{1992} & \multirow{2}{*}{$\begin{array}{l}\text { San Bernardino- } \\
\text { E \& Hospitality }\end{array}$} & FN & \multirow{2}{*}{4.48} & 0.36 & 58.06 & \multirow{2}{*}{271.4} \\
\hline 2 & & & & FP & & 0.45 & 61.38 & \\
\hline 3 & \multirow{2}{*}{ Chi-Chi } & \multirow{2}{*}{1999} & \multirow{2}{*}{ CHY101 } & $\mathrm{FN}$ & \multirow{2}{*}{1.29} & 0.59 & 110.73 & \multirow{2}{*}{258.9} \\
\hline 4 & & & & FP & & 0.49 & 140.39 & \\
\hline 5 & \multirow{2}{*}{ Duzce } & \multirow{2}{*}{1999} & \multirow{2}{*}{ Duzce } & $\mathrm{FN}$ & \multirow{2}{*}{1.09} & 0.39 & 67.53 & \multirow{2}{*}{276} \\
\hline 6 & & & & FP & & 0.56 & 86.28 & \\
\hline 7 & \multirow{2}{*}{ Erzincan } & \multirow{2}{*}{1992} & \multirow{2}{*}{ Erzincan } & FN & \multirow{2}{*}{1.12} & 0.55 & 106.85 & \multirow{2}{*}{274.5} \\
\hline 8 & & & & FP & & 0.47 & 50.72 & \\
\hline 9 & \multirow{2}{*}{ Hector Mine } & \multirow{2}{*}{1999} & \multirow{2}{*}{ Amboy } & $\mathrm{FN}$ & \multirow{2}{*}{2.57} & 0.50 & 67.22 & \multirow{2}{*}{271.4} \\
\hline 10 & & & & FP & & 0.52 & 56.21 & \\
\hline 11 & \multirow{2}{*}{ Imperial Valley } & \multirow{2}{*}{1979} & \multirow{2}{*}{$\begin{array}{l}\text { EC County } \\
\text { Center FF }\end{array}$} & $\mathrm{FN}$ & \multirow{2}{*}{2.06} & 0.37 & 112.07 & \multirow{2}{*}{192.1} \\
\hline 12 & & & & FP & & 0.46 & 88.36 & \\
\hline
\end{tabular}

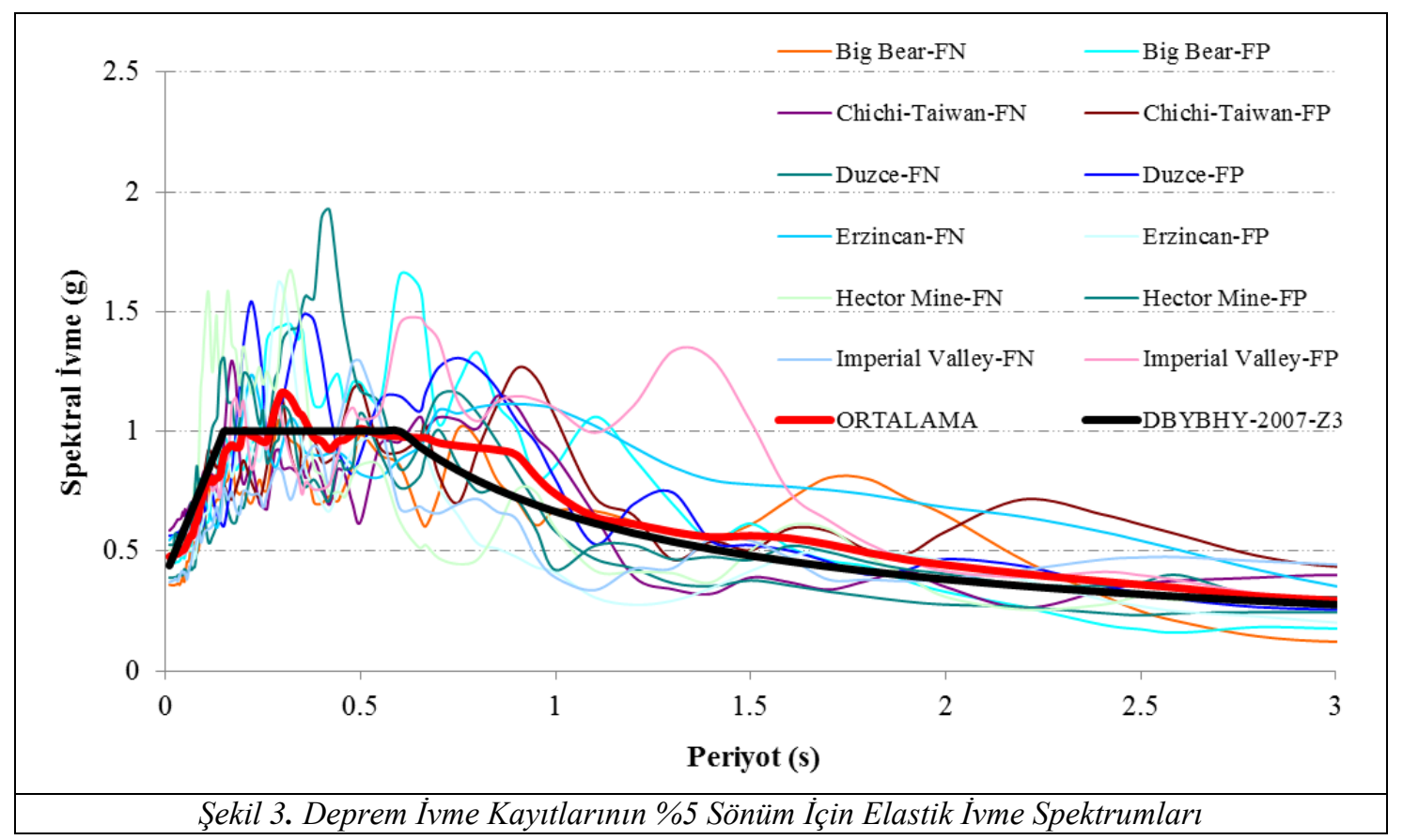

yüksekliğine oranlanarak "göreli kat ötelenme oranı” değişkenleri hesaplanmıştır. Mevcut çalışmada modellenen yapı grupları her iki doğrultu için 12 tane yer hareketi kaydıyla gerçekleştirilen analizlerden bulunan değişkenlere ait minimum, maksimum, standart sapma ve ortalama değerler açısından istatistiksel olarak incelenmiştir.

Doğrusal elastik (linear) ve doğrusal elastik olmayan (nonlinear) analiz sonuçlarına göre 3-,6- ve 9-katlı binaların taban kesme kuvveti oranı verileri Tablo 3'de verilmiştir. Doğrusal analiz ortalama sonuçlarına göre 6- ve 9- katlı binalara ait taban kesme kuvveti oranları birbirine yakın iken 3-katlı binaya göre \%25 dolayında düşük çıkmıştır. Doğrusal olmayan analizde ise taban kesme oranlarının kat sayısı ile ters orantılı bir şekilde değiştiği gözlemlenmiştir. Taban kesme kuvveti oranlarına ait maksimum ve minimum değerler birbirine oranlandığında 3-,6ve 9-katlı binaların doğrusal analizinde sırasıyla $2.11,1.73$ ve 2.70 değerlerini alırken doğrusal olmayan analizinde ise 1.29, 1.19 ve 1.35 değerlerini almaktadır. Görüldüğü gibi doğrusal olmayan analizden bulunan maksimum/minimum taban kesme oranı değerleri doğrusal analize göre daha düşüktür. $\mathrm{Bu}$ da doğrusal olmayan analizde plastik mafsallar vasıtasıyla elemanların dayanımlarının sınırlandırılmasına ve gerçek dayanımlarının kullanılmasıyla açıklanabilir. Ayrıca deprem büyüklüğünün ve kullanılan deprem sayısının artması da bu farkın açılmasına sebep olabilmektedir.

Tablo 3'de taban kesme kuvveti oranı için verilen standart sapma değerleri ve Şekil 4'ten de anlaşılacağı üzere doğrusal analiz sonuçları doğrusal olmayan analize göre daha geniş bir bant aralığında dağılmaktadır. 
European Journal of Science and Technology

Tablo 3. 3-,6-ve 9-katlı Doğrusal (Linear) ve Doğrusal Olmayan (Nonlinear) Binaların Taban Kesme Kuvveti Oranlart

\begin{tabular}{|c|c|c|c|c|c|c|c|c|c|c|c|c|}
\hline \multirow{3}{*}{ Depremler } & \multicolumn{4}{|c|}{ 3-katl1 yap1 } & \multicolumn{4}{|c|}{ 6-katl1 yap1 } & \multicolumn{4}{|c|}{ 9-katl1 yap1 } \\
\hline & \multicolumn{2}{|c|}{ Linear } & \multicolumn{2}{|c|}{ Nonlinear } & \multicolumn{2}{|c|}{ Linear } & \multicolumn{2}{|c|}{ Nonlinear } & \multicolumn{2}{|c|}{ Linear } & \multicolumn{2}{|c|}{ Nonlinear } \\
\hline & $\mathrm{X}$ & $\mathrm{Y}$ & $\mathrm{X}$ & $\mathrm{Y}$ & $\mathrm{X}$ & $\mathrm{Y}$ & $\mathrm{X}$ & $\mathrm{Y}$ & $\mathrm{X}$ & $\mathrm{Y}$ & $\mathrm{X}$ & $\mathrm{Y}$ \\
\hline Big Bear-FN & 0.85 & 0.86 & 0.50 & 0.55 & 0.72 & 0.78 & 0.31 & 0.33 & 0.54 & 0.87 & 0.18 & 0.18 \\
\hline Big Bear-FP & 1.21 & 1.23 & 0.53 & 0.54 & 1.07 & 0.97 & 0.34 & 0.37 & 1.04 & 0.98 & 0.18 & 0.18 \\
\hline Chichi-FN & 0.73 & 0.76 & 0.51 & 0.55 & 0.88 & 0.79 & 0.33 & 0.35 & 0.83 & 0.84 & 0.18 & 0.17 \\
\hline & 0.96 & 0.74 & 0.54 & 0.55 & 0.79 & 0.92 & 0.31 & 0.34 & 0.75 & 0.66 & 0.18 & 0.17 \\
\hline Duzc & 1.18 & 1.22 & 0.53 & 0.58 & 0.65 & 0.95 & 0.30 & 0.33 & 0.88 & 0.94 & 0.17 & 0.17 \\
\hline Duzce-FP & 1.01 & 1.16 & 0.55 & 0.60 & 0.92 & 0.89 & 0.31 & 0.34 & 1.13 & 1.02 & 0.20 & 0.17 \\
\hline Erzincan-FN & 0.83 & 0.91 & 0.56 & 0.60 & 0.77 & 0.72 & 0.35 & 0.37 & 0.89 & 0.89 & 0.24 & 0.21 \\
\hline & 35 & 1.15 & 0.52 & 0.55 & 0.84 & 0.86 & 0.30 & 0.32 & 0.71 & 0.51 & 0.20 & 0.18 \\
\hline Hecto & 1.39 & 1.41 & 0.49 & 0.50 & 0.53 & 0.78 & 0.30 & 0.32 & 0.44 & 0.39 & 0.17 & 0.17 \\
\hline & 0.95 & 0.82 & 0.44 & 0.46 & 0.74 & 0.86 & 0.30 & 0.32 & 0.80 & 0.75 & 0.19 & 0.17 \\
\hline & 0.69 & 0.63 & 0.47 & 0.50 & 0.60 & 1.00 & 0.29 & 0.32 & 0.52 & 0.57 & 0.19 & 0.17 \\
\hline Impe & 0.88 & 0.77 & 0.50 & 0.53 & 1.10 & 0.85 & 0.33 & 0.35 & 1.21 & 0.91 & 0.18 & 0.17 \\
\hline Maks & 1.39 & 1.41 & 0.56 & 0.60 & 1.10 & 1.00 & 0.35 & 0.37 & 1.21 & 1.02 & 0.24 & 0.21 \\
\hline Minimum & 0.69 & 0.63 & 0.44 & 0.46 & 0.53 & 0.72 & 0.29 & 0.32 & 0.44 & 0.39 & 0.17 & 0.17 \\
\hline Standart Sapma & 0.23 & 0.25 & 0.03 & 0.04 & 0.17 & 0.09 & 0.02 & 0.02 & 0.24 & 0.20 & 0.02 & 0.01 \\
\hline Ortalama & 1.00 & 0.97 & 0.51 & 0.54 & 0.80 & 0.86 & 0.31 & 0.34 & 0.81 & 0.78 & 0.19 & 0.18 \\
\hline
\end{tabular}

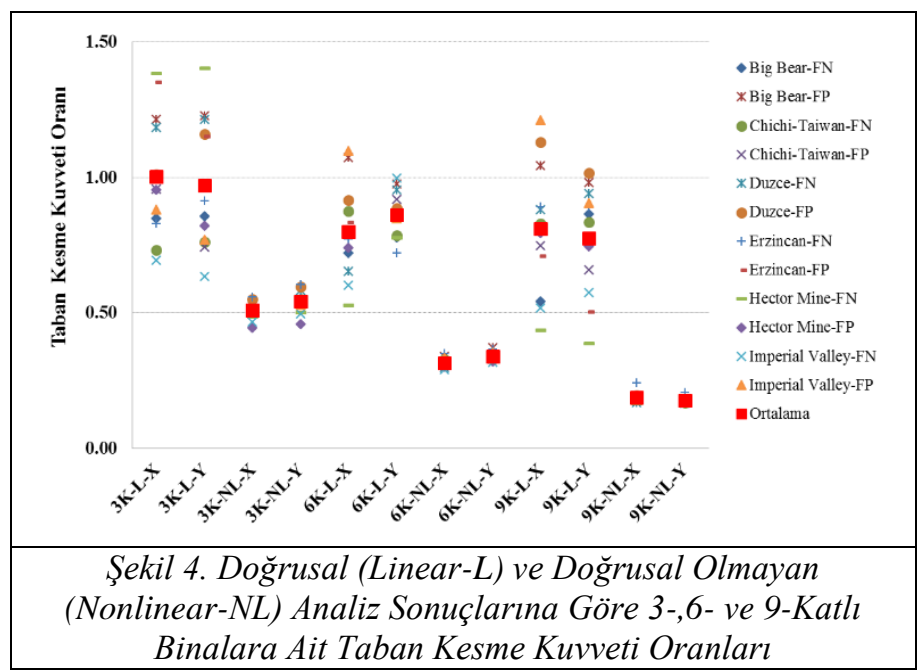

Doğrusal elastik (linear) ve doğrusal elastik olmayan (nonlinear) analiz sonuçlarına göre 3-,6- ve 9-katlı binaların tepe noktası ötelenme oranları Tablo 4'de gösterilmiştir. Tepe noktası ötelenme oranına ait maksimum değerler farklı deprem ivme kayıtları tarafindan elde edilmiştir, yani aynı deprem ivme kaydı tüm binalarda aynı etkiyi yaratmamıştır. Bunu da binaların sahip olduğu periyotların seçilen deprem ivme kayıtlarına ait tepki spektrumlarında farklı noktalara denk gelmesi sebebiyle depremlerin binaları farklı büyüklükte etkilemelerinden dolayı binalarda değişik deplasman taleplerinin elde edilmesine bağlayabiliriz. Ayrıca deplasman talep farklılı̆̆ına doğrusal ve doğrusal olmayan analiz açısından bakıldığında depremin büyüklüğünün artışıyla birlikte doğrusal analizde elemanların dayanımı sürekli artma eğiliminde olacak doğrusal olmayan analizde ise sadece akma anına kadar artacak sonra sabit kalacaktır. Bu da doğal olarak deplasman talebini etkileyecektir. Hem doğrusal hem doğrusal olmayan analiz sonuçlarına bakıldığında binalar arasında deplasman talepleri açısından en riskli grup 9-katlı binalardır. Ortalama tepe noktası ötelenme oranları göz önüne alınarak yapılan değerlendirmede 6- ve 9-katlı binaların değerleri 3- katlı bina değerlerine oranlandığında sirasıyla doğrusal analizde $1.31,1.52$ ve doğrusal olmayan analizde ise 1.58, 2.15 değerleri elde edilmektedir. Görüldüğü gibi doğrusal analizden doğrusal olmayan analize geçildiğinde binalar arasındaki deplasman farkları da artmaktadır.

Her bir binanın 12 kayıt için tepe noktası deplasmanları değerlendirildiğinde minimum ve maksimum değerler arasındaki fark 3-,6- ve 9-katlı binaların doğrusal analizinde sırasıyla 2.14, 1.77 ve 2.82 kat olurken doğrusal olmayan analizinde ise $2.2,4.05$ ve 5.06 kat arasında değişmektedir. Elde edilen sonuçlara göre doğrusal olmayan analizde elde edilen tepe noktası ötelenme oranlarının minimum ve maksimum değerleri arasındaki fark doğrusal analize göre daha fazladır. Doğrusal olmayan analizde elemanların rijitliği aldığ elemanlar arası yeniden dağılım gerçekleşmekteyken buna karşın doğrusal analizde rijitlik değişimi dikkate alınmamaktadır. Bu da iki analizden bulunan deplasman talep farklılığına yol açmaktadır. Elde edilen değerler, seçilen ivme kayıtlarının binalarda oldukça farklı hasar seviyelerinde deplasman talebi oluşturacağının göstergesidir (Şekil 5).

Doğrusal elastik (linear) ve doğrusal elastik olmayan (nonlinear) analiz sonuçlarına göre 3-,6- ve 9-katlı yapılara ait göreli kat ötelenmesi verilerinin kat yüksekliğine oranlanmasılyla elde edilen maksimum göreli kat ötelenme oranları sonuçları Tablo 5'de verilmiştir. Göreli kat ötelenme değerlerine bakıldığında tepe noktası ötelenme sonuçlarıyla uyumlu bir eğilim görülmektedir. Ortalama göreli kat ötelenme oranları dikkate alınarak yapılan karşış̧tırmada 9-katlı binalara ait değerler 3- ve 6- katlı bina değerlerine oranlandığında sırasıyla doğrusal analizde $1.89,1.12$ ve doğrusal olmayan analizde ise 2.76, 1.25 değerleri hesaplanmaktadır. Ortalama göreli kat ötelenme oranları tepe noktası ötelenme oranlarına bölündüğünde 3-, 6- ve 9- katlı binalarda sırasıyla doğrusal analizde 1.13, 1.46 ve 1.41 değerleri elde edilirken doğrusal olmayan analizde ise $1.34,1.88$ ve 1.72 değerleri bulunmaktadır. Sonuçlara göre doğrusal olmayan analizde göreli kat/tepe noktası ötelenme oranının doğrusal analize göre daha fazla hesaplandığı anlaşılmaktadır. Şekil 6'da görüldüğü üzere, Erzincan-FN ve Chichi-Taiwan-FP ivme kayıtlarının göreli kat ötelenme deplasman talepleri 6- ve 9- katlı binaların doğrusal olmayan analizinde diğer kayıtların sonuçlarına göre oldukça yüksek çıkmıştır. 
Tablo 4. 3-,6-ve 9-katlı Doğrusal (Linear) ve Doğrusal Olmayan (Nonlinear) Binaların Tepe Noktası Ötelenme Oranları (\%)

\begin{tabular}{|c|c|c|c|c|c|c|c|c|c|c|c|c|}
\hline \multirow{3}{*}{ Depremler } & \multicolumn{4}{|c|}{ 3-katlı yap1 } & \multicolumn{4}{|c|}{ 6-katl1 yap1 } & \multicolumn{4}{|c|}{ 9-katlı yap1 } \\
\hline & \multicolumn{2}{|c|}{ Linear } & \multicolumn{2}{|c|}{ Nonlinear } & \multicolumn{2}{|c|}{ Linear } & \multicolumn{2}{|c|}{ Nonlinear } & \multicolumn{2}{|c|}{ Linear } & \multicolumn{2}{|c|}{ Nonlinear } \\
\hline & $\mathrm{X}$ & $\mathrm{Y}$ & $\mathrm{X}$ & $\mathrm{Y}$ & $\mathrm{X}$ & $\mathrm{Y}$ & $\mathrm{X}$ & $\mathrm{Y}$ & $\mathrm{X}$ & $\mathrm{Y}$ & $\mathrm{X}$ & $\mathrm{Y}$ \\
\hline Big Bear-FN & 0.34 & 0.38 & 0.32 & 0.35 & 0.49 & 0.49 & 0.58 & 0.46 & 0.38 & 0.74 & 0.51 & 0.55 \\
\hline Big Bear-FP & 0.49 & 0.56 & 0.40 & 0.40 & 0.83 & 0.61 & 0.78 & 0.73 & 0.73 & 0.90 & 0.88 & 1.01 \\
\hline Chichi-FN & 0.30 & 0.33 & 0.32 & 0.35 & 0.58 & 0.45 & 0.75 & 0.60 & 0.63 & 0.76 & 1.00 & 1.10 \\
\hline Chichi-FP & 0.38 & 0.34 & 0.52 & 0.44 & 0.55 & 0.54 & 0.78 & 0.61 & 0.58 & 0.51 & 1.20 & 1.33 \\
\hline Duzce-FN & 0.47 & 0.55 & 0.47 & 0.50 & 0.51 & 0.62 & 0.79 & 0.72 & 0.67 & 0.85 & 0.41 & 0.42 \\
\hline Duzce-FP & 0.39 & 0.52 & 0.51 & 0.56 & 0.69 & 0.57 & 0.81 & 0.78 & 0.72 & 0.97 & 0.73 & 0.76 \\
\hline Erzincan-FN & 0.32 & 0.41 & 0.60 & 0.52 & 0.52 & 0.43 & 1.49 & 1.20 & 0.65 & 0.78 & 1.90 & 2.15 \\
\hline Erzincan-FP & 0.55 & 0.53 & 0.38 & 0.45 & 0.58 & 0.52 & 0.34 & 0.33 & 0.51 & 0.48 & 0.49 & 0.59 \\
\hline Hector-FN & 0.51 & 0.64 & 0.40 & 0.46 & 0.40 & 0.52 & 0.36 & 0.33 & 0.31 & 0.34 & 0.38 & 0.42 \\
\hline Hector-FP & 0.38 & 0.37 & 0.25 & 0.28 & 0.52 & 0.56 & 0.34 & 0.38 & 0.58 & 0.59 & 0.63 & 0.68 \\
\hline Imperial-FN & 0.28 & 0.28 & 0.27 & 0.32 & 0.45 & 0.64 & 0.52 & 0.40 & 0.40 & 0.51 & 0.83 & 0.97 \\
\hline Imperial-FP & 0.35 & 0.34 & 0.35 & 0.33 & 0.65 & 0.43 & 0.71 & 0.56 & 0.86 & 0.80 & 0.92 & 1.04 \\
\hline Maksimum & 0.55 & 0.64 & 0.60 & 0.56 & 0.83 & 0.64 & 1.49 & 1.20 & 0.86 & 0.97 & 1.90 & 2.15 \\
\hline Minimum & 0.28 & 0.28 & 0.25 & 0.28 & 0.40 & 0.43 & 0.34 & 0.33 & 0.31 & 0.34 & 0.38 & 0.42 \\
\hline Standart Sapma & 0.09 & 0.12 & 0.11 & 0.09 & 0.12 & 0.07 & 0.31 & 0.25 & 0.16 & 0.19 & 0.42 & 0.48 \\
\hline Ortalama & 0.40 & 0.44 & 0.40 & 0.41 & 0.56 & 0.53 & 0.69 & 0.59 & 0.58 & 0.69 & 0.82 & 0.92 \\
\hline
\end{tabular}

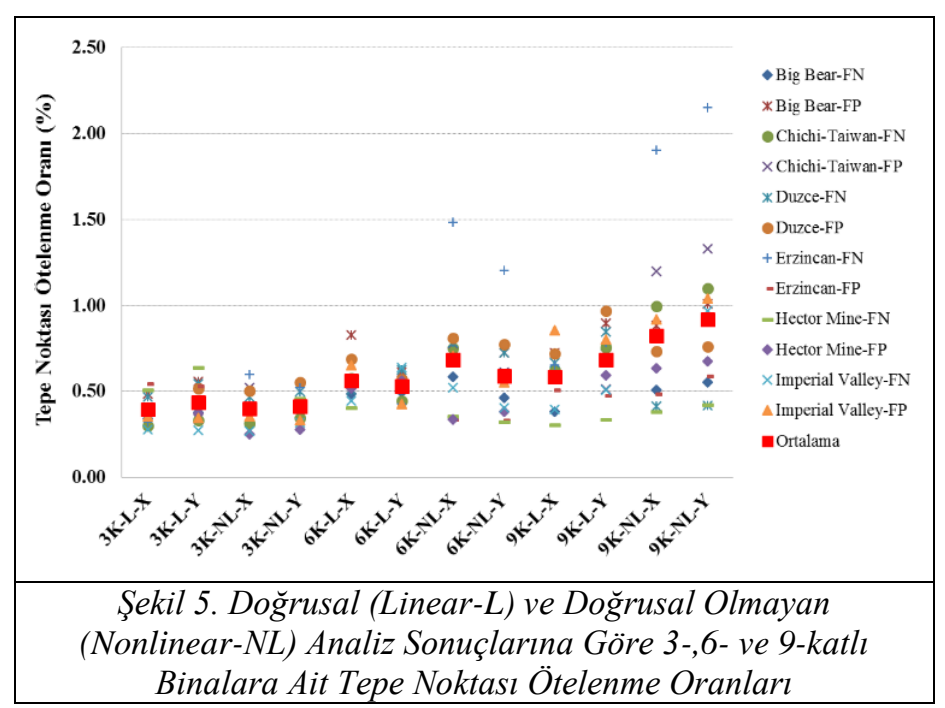

Taban kesme kuvveti, tepe noktası ötelenme ve göreli kat ötelenme oranları değişkenleri doğrusal ve doğrusal olmayan analiz açısından değerlendirilerek Şekil $7 \mathrm{a}, 7 \mathrm{~b}$ ve $7 \mathrm{c}$ 'de gösterilmiştir. Doğrusal analiz ile doğrusal olmayan analiz arasındaki taban kesme kuvveti oranları farkı 3-, 6- ve 9- katlı binalarda sırasıyla $1.88,2.55$ ve 4.34 'e kadar çıkabilmektedir (Şekil 7a). Tepe noktası ötelenme oranlarında ise doğrusal analizde doğrusal olmayan analiz sonuçlarına göre 3- katlı binalarda fark sınırlı iken 6- ve 9- katlı binalarda sırasıyla \%14 ve \%27 oranında düşük değerler hesaplanmıştır (Şekil 7b). Benzer biçimde göreli kat ötelenme oranlarına bakıldığında doğrusal analizde doğrusal olmayan analiz verilerine göre 3-, 6- ve 9- katlı binalarda sırasıyla yaklaşık olarak \%13, \% 33 ve \%40 oranında eksik bulunmuştur (Şekil 7c).

Tablo 5. 3-,6- ve 9-katlı Doğrusal (Linear) ve Doğrusal Olmayan (Nonlinear) Binaların Göreli Kat Ötelenme Oranı Değerleri (\%)

\begin{tabular}{|c|c|c|c|c|c|c|c|c|c|c|c|c|}
\hline \multirow{3}{*}{ Depremler } & \multicolumn{4}{|c|}{ 3-katl1 yap1 } & \multicolumn{4}{|c|}{ 6-katlı yap1 } & \multicolumn{4}{|c|}{ 9-katlı yap1 } \\
\hline & \multicolumn{2}{|c|}{ Linear } & \multicolumn{2}{|c|}{ Nonlinear } & \multicolumn{2}{|c|}{ Linear } & \multicolumn{2}{|c|}{ Nonlinear } & \multicolumn{2}{|c|}{ Linear } & \multicolumn{2}{|c|}{ Nonlinear } \\
\hline & $\mathrm{X}$ & $\mathrm{Y}$ & $\mathrm{X}$ & $\mathrm{Y}$ & $X$ & $\mathrm{Y}$ & $\mathrm{X}$ & $\mathrm{Y}$ & $\mathrm{X}$ & $\mathrm{Y}$ & $\mathrm{X}$ & $\mathrm{Y}$ \\
\hline $\mathrm{Big}$ Rear_F & 0.38 & 0.47 & 0.41 & 0.47 & 0.73 & 0.69 & 1.06 & 0.79 & 0.53 & 1.07 & 0.97 & 1.02 \\
\hline & 61 & 0.65 & 54 & 0.54 & 16 & 0.85 & 1.59 & 1.51 & 1.03 & 1.27 & 1.57 & 1.73 \\
\hline & 38 & 0.41 & 0.42 & 0.49 & 0.88 & 0.64 & 1.43 & 1.06 & 0.83 & 1.06 & 1.73 & 1.89 \\
\hline & 39 & 0.39 & 0.73 & 0.60 & 0.81 & 0.77 & 1.49 & 1.15 & 0.79 & 0.80 & 2.00 & 2.23 \\
\hline & 52 & 0.59 & 0.63 & 0.68 & 0.72 & 0.86 & 1.40 & 1.33 & 0.91 & 1.19 & 0.80 & 0.83 \\
\hline & & 0.56 & & 0.79 & 98 & 0.80 & 1.53 & 1.2 & 1.07 & 1.31 & 1.30 & 1.30 \\
\hline & .38 & 0.45 & 0.85 & 0.78 & 0.78 & 0.60 & 2.91 & 2.27 & 0.86 & 1.14 & 3.10 & 3.36 \\
\hline & 56 & 0.57 & 0.52 & 0.62 & 0.87 & 0.75 & 0.63 & 0.63 & 0.72 & 0.65 & 0.85 & 0.97 \\
\hline & & 0.68 & 0.51 & 0.55 & 0.60 & 0.70 & 0.61 & 0.59 & 0.45 & 0.48 & 0.72 & 0.79 \\
\hline & & 0.46 & & 0.31 & & 0.77 & 0.6 & 0.69 & 0.81 & 0.91 & 1.17 & 1.23 \\
\hline & 29 & 0.31 & 0.33 & 0.40 & 0.65 & 0.88 & 0.92 & 0.70 & 0.55 & 0.73 & 1.41 & 1.59 \\
\hline Imperial-FP & 37 & 0.40 & 0.45 & 0.43 & 1.17 & 0.75 & 1.39 & 1.07 & 1.20 & 1.14 & 1.63 & 1.85 \\
\hline & 61 & 0.68 & 0.85 & 0.79 & 1.17 & 0.88 & 2.91 & 2.27 & 1.20 & 1.31 & 3.10 & 3.36 \\
\hline & & 0.31 & 0 & 0.31 & 0.60 & 0.60 & 0.6 & 0.59 & 0.45 & 0.48 & 0.72 & 0.79 \\
\hline & & 0.12 & & 0.15 & & 0.09 & 0.6 & 0.49 & 0.23 & 0.26 & 0.66 & 0.73 \\
\hline Ortalama & 0.45 & 0.50 & 0.53 & 0.56 & 0.84 & 0.76 & 1.30 & 1.11 & 0.81 & 0.98 & 1.44 & 1.56 \\
\hline
\end{tabular}



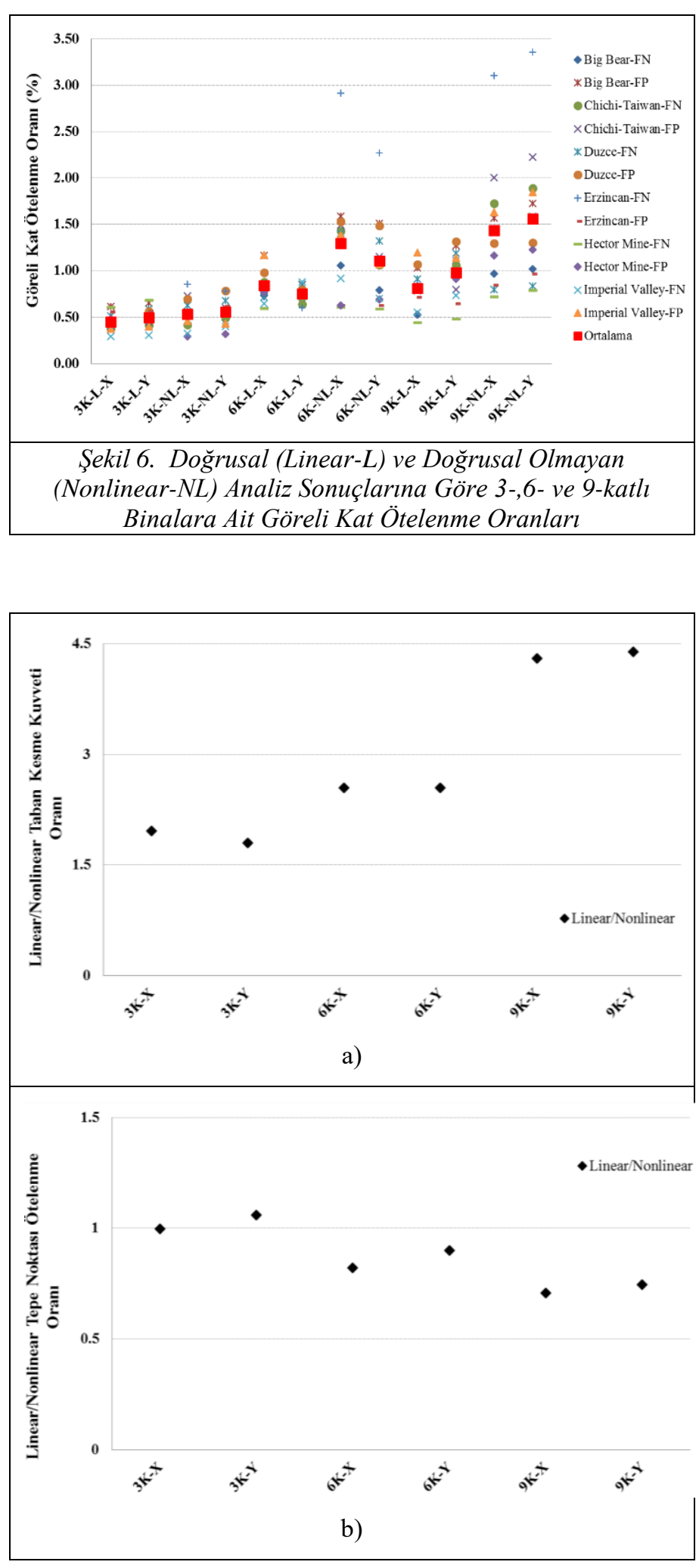

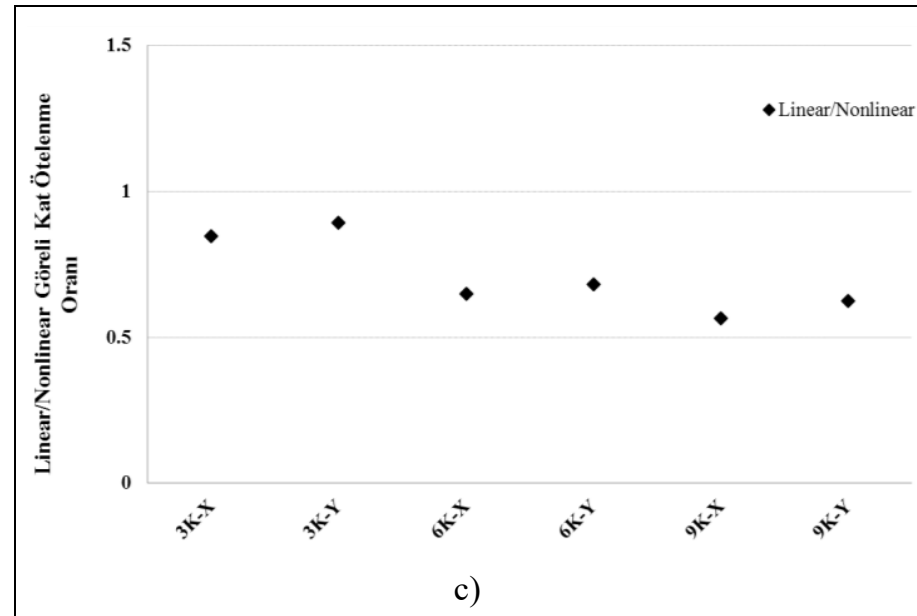

Şekil 7. Ortalama Taban Kesme Kuvveti, Tepe Noktasl ve Göreli Kat Ötelenme Oranlarının Doğrusal (Linear) ve Doğrusal Olmayan (Nonlinear) Analiz Sonuçlarına Göre Karşılaştırılması

\section{Doğrusal (Linear)}

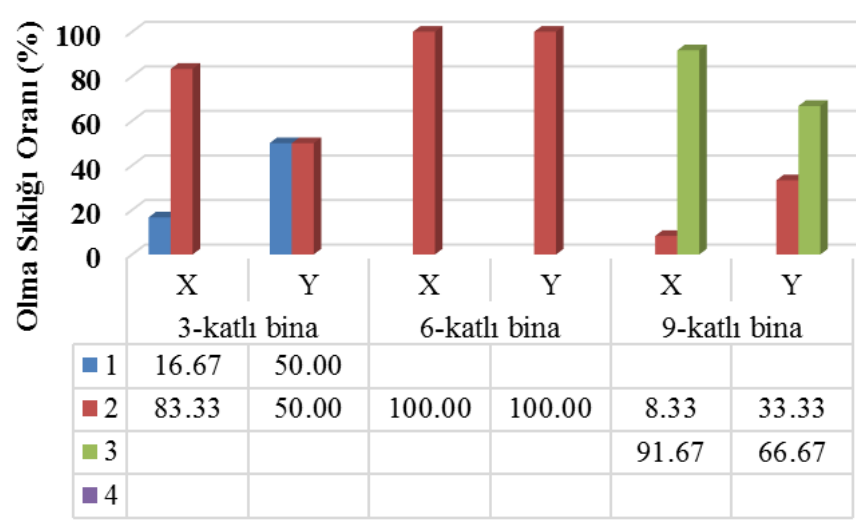

a)

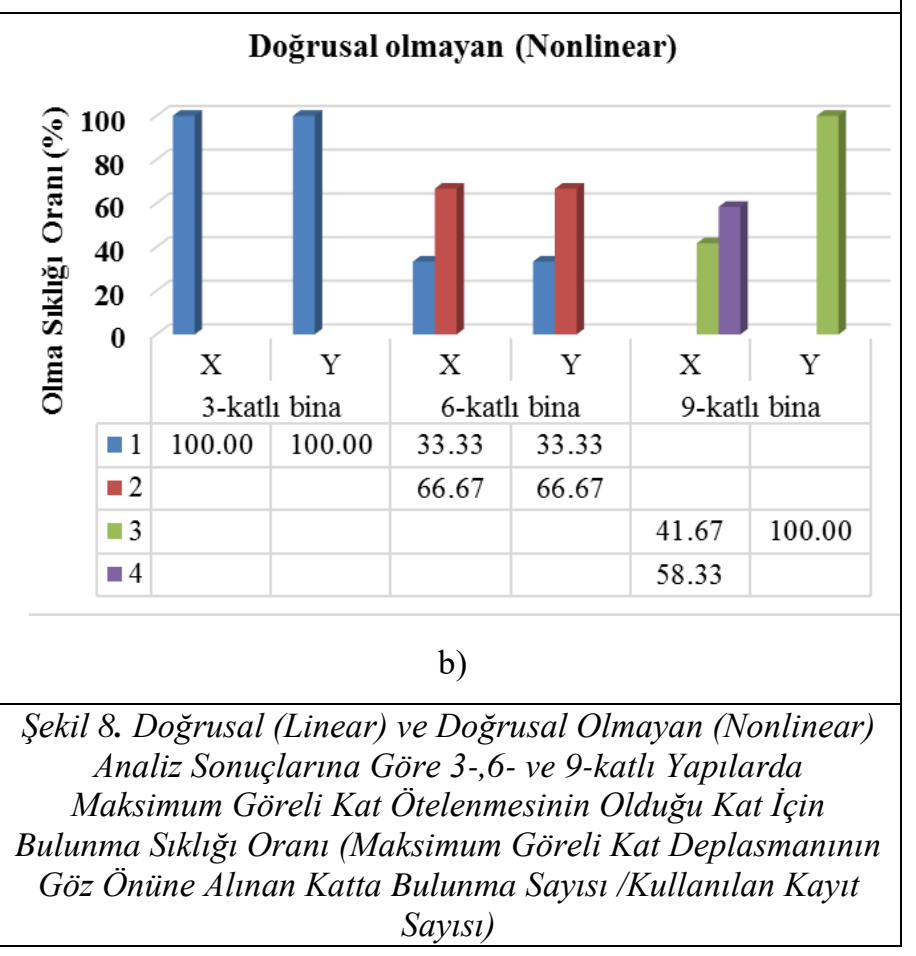

Göreli kat deplasmanının maksimum değerinin bulunduğu kat belirlenerek Şekil 8a ve 8b'de gösterilmiştir. Maksimum 
göreli kat deplasmanı doğrusal analizde 3- katlı binada 1. ve 2 . katta, 6- katlı binada 2. katta ve 9-katlı binada 2. ve 3. katta oluşmaktadır (Şekil 8a). Doğrusal olmayan analizde ise maksimum göreli kat deplasmanı 3-katlı binada 1. katta, 6- katlı binada 1. ve 2. katta ve 9-katlı binada 3. ve 4. katta oluşmaktadır (Şekil 8b). Doğrusal analizden doğrusal olmayana analize geçildiğinde maksimum göreli kat deplasmanı 3- ve 6- katlı binalarda alt katlara doğru oluşma yönelimi gösterirken 9- katlı binada ise üst katlara doğru çıkmaktadır. Maksimum göreli kat deplasmanının 9- katlı binada üst katlarda çıkması kolonların eksenel yüke bağlı çatlamış kesit rijitliği katsayılarının azalmasıyla açıklanabilir.

\section{Sonuç}

Düşük ve orta yükseklikteki betonarme konut tipi yapılarının 3-, 6- ve 9- katlı olarak yansıtıldığı çalışmada her bir bina grubu için 2007 Türk Deprem Yönetmeliği dikkate alınmıştır. Bu kapsamda, 3-B modellerin her iki doğrultusunda gerçek deprem kayıtları seçilerek zaman tanım alanında doğrusal elastik ve doğrusal elastik olmayan analizlerle taban kesme ve deplasman talepleri bulunmuştur. Gerçek depremlerden elde edilen kayıtlardan alınan 12 adet yer hareketi kaydıyla toplamda 144 adet analiz yapılmıştır. Analizler sonucu elde edilen taban kesme kuvveti, tepe noktası ötelenme ve maksimum göreli kat ötelenme oranlarına ait değerleri araştırılmıştır. Çalışmadan elde edilen bulgular aşağıda özetlenmiştir.

> Doğrusal analiz ortalama sonuçlarına göre 6- ve 9- katlı binalara ait taban kesme kuvveti oranları birbirine yakın olmakla birlikte 3-katlı binaya göre \%25 dolayında düşük çıkmıştır. Doğrusal olmayan analizde ise taban kesme oranlarının kat sayısı ile ters orantılı olarak değiştiği görülürken 6- ve 9- katlı binada sırasıyla 3-katlı binaya göre $\% 38$ ve $\% 65$ oranında az hesaplanmıştır.

> 6- ve 9-katlı binalara ait ortalama tepe noktası ötelenme oranı verileri 3- katlı binalara oranlandığında sırasıyla doğrusal analizde $1.31,1.52$ ve doğrusal olmayan analizde ise 1.58 , 2.15 değerleri elde edilmektedir. Sonuçlara göre doğrusal analizde doğrusal olmayan analize göre binalar arasındaki deplasman farkları artmaktadır.

$>$ Ortalama göreli kat ötelenme oranlarının karşılaştırılmasında 9-katlı binalara ait değerler 3- ve 6- katlı bina değerlerine oranlandığında sirasıyla doğrusal analizde $1.89,1.12$ ve doğrusal olmayan analizde ise $2.76,1.25$ değerleri hesaplanmaktadır.

$>$ Doğrusal ile doğrusal olmayan analiz sonuçları karşılaştırıldığında doğrusal analizde taban kesme kuvveti oranları yüksek olurken doğrusal olmayan analizde ise tepe noktası ve göreli kat ötelenme değerleri yüksek hesaplanmıştır.

> Göreli kat deplasmanına ait maksimum değerin oluştuğu kata bakıldığında doğrusal analizden doğrusal olmayan analize geçiş yapıldığında maksimum göreli kat deplasmanı 3- ve 6katlı binalarda alt katlara doğru oluşma eğilimi gösterirken 9katlı binada ise üst katlara doğru çıkmaktadır.

\section{Kaynakça}

Beşikçi, O. B. (2013). Düşük ve orta yükseklikteki yumuşak katlı binaların deplasman taleplerinin doğrusal elastik olmayan analizle tahmini, Pamukkale Üniversitesi Fen Bilimleri Enstitüsü, yüksek lisans tezi.

Bilgin, H. (2007). Kamu yapılarının deprem performanslarının doğrusal ötesi analiz yöntemleriyle değerlendirilmesi ve çözüm önerileri, Pamukkale Üniversitesi Fen Bilimleri Enstitüsü, doktora tezi.

Çelik, S. (2011). Düşük ve orta yükseklikteki binaların deplasman taleplerinin doğrusal elastik olmayan zaman tanım alanında analizle tahmini, Pamukkale Üniversitesi Fen Bilimleri Enstitüsü, yüksek lisans tezi.

DBYBHY-2007. (2007). Deprem Bölgelerinde Yapılacak Binalar Hakkında Yönetmelik, Bayındırlık ve İskân Bakanlığı, Ankara.

Inel, M., Meral, E., \& Ozmen, H.B. (2014). Seismic displacement demands of low and mid-rise rc buildings with nonlinear static and dynamic analyses. Second European Conference on Earthquake Engineering and Seismology, August 25-29, 2014, Istanbul.

Inel, M., \& Meral, E. (2016). Seismic performance of rc buildings subjected to past earthquakes in Turkey. Earthquakes and Structures, 11(3): 483-503.

İnel, M., Çelik, S., Özmen, H. B., \& Önür, Ö. (2011). Betonarme binaların deplasman taleplerinin 3-B doğrusal elastik olmayan dinamik analizle değerlendirilmesi. 1. Türkiye Deprem Mühendisliği ve Sismoloji Konferansl, 11-14 Ekim 2011, Ankara.

İnel, M., Meral, E., \& Özmen, H.B. (2013). Betonarme binalarda eşdeğer tek serbestlik dereceli sistem ve 3-B doğrusal elastik olmayan dinamik analiz deplasman taleplerinin karşılaştırılması. 2. Türkiye Deprem Mühendisliği ve Sismoloji Konferansl, 25-27 Eylül 2013, Hatay.

Mander, J.B., Priestley, M.J., \& Park, R. (1988). Theoretical stress-strain model for confined concrete. Journal of Structural Engineering, 114(8): 1804-1826.

Meral, E. (2010). Düşük ve orta yükseklikteki betonarme yapıların sismik deplasman taleplerinin değerlendirilmesi, Pamukkale Üniversitesi Fen Bilimleri Enstitüsü, yüksek lisans tezi.

Önür, Ö. (2011). Düşük ve orta yükseklikteki betonarme yapıların deplasman taleplerinin doğrusal elastik zaman tanım alanında analizle belirlenmesi, Pamukkale Üniversitesi Fen Bilimleri Enstitüsü, yüksek lisans tezi.

Özer, E., Kamal, M., \& İnel, M. (2017). Comparison of linear and nonlinear seismic behavior of 2D and 3D rc buildings. International Journal of Engineering \& Applied Sciences, 9(4): 17-27.

Özmen, H.B. (2011). Düşük ve orta yükseklikteki betonarme yapıların deprem performanslarını etkileyen faktörlerin irdelenmesi, Pamukkale Üniversitesi Fen Bilimleri Enstitüsü, doktora tezi.

Peer. (2011). Pacific Earthquake Engineering Research Center, http://peer.berkeley.edu (Erişim tarihi: 10 Ekim 2021).

SAP2000 V-19. (2017). Integrated finite element analysis and design of structures basic analysis reference manual. Computers and Structures Inc., Berkeley (CA, USA).

SEMAp. (2008). Sarg1 etkisi modelleme analiz programı. Tubitak Proje No: 105M024. 